\title{
Occurrence of polychlorinated dibenzo-p-dioxins, dibenzofurans and biphenyls pollution in sediments from the Haihe River and Dagu Drainage River in Tianjin City, China
}

\author{
Hanxia Liu ${ }^{\text {a,c }}$, Qinghua Zhang ${ }^{\text {a }}$, Yawei Wang ${ }^{\text {a }}$, Zongwei Cai ${ }^{\text {b,a }}$, Guibin Jiang ${ }^{\text {a,* }}$ \\ ${ }^{a}$ State Key Laboratory of Environmental Chemistry and Ecotoxicology, Research Center for Eco-Environmental Sciences, \\ Chinese Academy of Sciences, 18 Shuangqing Road, Haidian District, Beijing 100085, China \\ ${ }^{\mathrm{b}}$ Dioxin Analysis Laboratory, Hong Kong Baptist University, Kowloon, Hong Kong SAR, China \\ ${ }^{c}$ Chinese Academy of Inspection and Quarantine, 3 Gaobeidian North Road, Chaoyang District, Beijing 100025, China
}

Received 30 May 2006; received in revised form 6 March 2007; accepted 26 March 2007

Available online 16 May 2007

\begin{abstract}
The pollution status of polychlorinated dibenzo- $p$-dioxins, dibenzofurans (PCDD/Fs) and polychlorinated biphenyls (PCBs) in the sediments of Haihe River, which is the most polluted among the seven largest basins in China, Dagu Drainage River flowing through a chemical industry zone, and two other rivers flowing into Bohai Sea in Tianjin City, China were investigated. The concentrations of PCDD/Fs and PCBs in the sediments from the mainstream of Haihe River were 1.3-26 pg I-TEQ g ${ }^{-1}$ dry weight (dw) and 0.07-

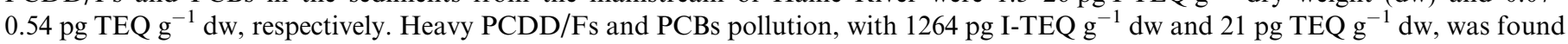
in sediment from Dagu Drainage River. The congener profiles of PCDD/Fs indicated that the principal contamination source was the production of pentachlorophenol (PCP) or PCP-Na in this area. The correlation between PCDD/Fs or PCBs and total organic matter (TOM) showed that PCDD/Fs or PCBs were independent on TOM.
\end{abstract}

(C) 2007 Published by Elsevier Ltd.

Keywords: PCDD/Fs; PCBs; Sediment; Haihe River; PCP; China

\section{Introduction}

With an area of $318000 \mathrm{~km}^{2}$ and flowing through many cities including Beijing and Tianjin, the Haihe River basin is the largest water system in northern China. Because of the rapid development of economy and explosion of city population, water pollution and shortage has become a stupendous obstacle to the sustainable development of the industry and agriculture in this area (Qin et al., 1998; Zhen et al., 1999). Now the Haihe River basin is the most polluted among the seven largest basins in China (Ding et al., 2005).

\footnotetext{
* Corresponding author. Tel./fax: +8610 62849179

E-mail address: gbjiang@rcees.ac.cn (G. Jiang).
}

As a traditional base of chemical industry in China, Tianjin has produced chloralkli, technical $\mathrm{HCH}$, lindane, chlorobenzene, and pentachlorophenol (PCP) for nearly 30-50 years (Gong et al., 2004; Hu et al., 2005). Although the production of PCP $(\mathrm{Na})$ has been generally forbidden, it is still manufactured by one of plants in this area for controlling the spreading of snailborne schistosomiasis in the south of China. In 1999, about 342000 tons alkali was produced and the capacity of chloralkali production in Tianjin was the second largest in China (Song, 2000, 2001). Many studies have reported that PCP production may be a very important source of polychlorinated dibenzo- $p$-dioxin and dibenzofurans (PCDD/Fs) (Hagenmaier and Hermann, 1987; Rappe et al., 1991; Bao et al., 1995; Zheng et al., 1997; Xu et al., 2000). Endemic chloracne among the workers in a plant located in this chemical industry zone had 
been noted since 1974 (Cheng et al., 1993). The prevalence of chloracne was $73.4 \%$ in total and $95.2 \%$ in trichlorobenzene tank area workers where PCDD/Fs levels were up to thousands of ppm. In addition, there are hundreds of small-scale chemical factories lacking of advanced technology and apparatus, which are potential contaminated sources in this area, including paper and pulp, printing and dyeing, leather, medicine, etc. (Zheng et al., 2001). Furthermore, abundant of wastewater is discharged without any treatment owing to the lack of adequate management and sewage treatment plants. The Dagu Drainage River is a channel especially used for wastewater discharge.

The pollutants, including heavy metal, organochlorine pesticides, 4-tert-octylphenol, 4-nonylphenol and bisphenol A etc., were found in Haihe River to be transported into Bohai Sea, which is located in the northeast of China, and seriously contaminate the marine environment (Jin et al., 2004; Shi et al., 2005; Yang et al., 2005). In addition, occurrence of PCDD/Fs and PCBs in mollusks and cores collected in or along Bohai Sea has been reported in several articles ( $\mathrm{Hu}$ et al., 2005; Wan et al., 2005; Zhao et al., 2005).

It is generally accepted that sediments constitute a sink for the hydrophobic compounds including PCBs and PCDD/Fs. The contamination of sediments may pose an unacceptable risk to human through bioaccumulation or biomagnification. In order to assess the potential risk, the status of the pollution of PCBs and PCDD/Fs in sediments from Haihe River, Dagu Drainage River and two other rivers flowing into Bohai Sea were investigated. Since PCDD/ Fs and PCBs are lipophilic organic compounds, the occurrence of PCDD/Fs or PCBs should in accord with TOM on the distance from sources. However, the correlation is disputed because concentrations of organic compounds in sediments are not all dependent on TOM of the sediments (Jeong et al., 2001; Buckley et al., 2004; Mai et al., 2005). Therefore, the correlation between TOM and the occurrence of $\mathrm{PCDD} / \mathrm{Fs}$ or $\mathrm{PCBs}$ in this research were also investigated to study the disputed correlation between TOM and organic compounds.

\section{Materials and methods}

\subsection{Sampling}

Sampling locations are shown in Fig. 1. Ten sediment samples along the Haihe River and three sediments from Dagu Drainage River were collected in July 2003. Starting from three tributary rivers, Beiyun River, Ziya River and Nanyun River, Haihe River flows through Tianjin City into Bohai Sea. Samples of H1-H8 were collected from the tributaries or typical sites along the Haihe River, H9 and $\mathrm{H} 10$ were just separated with a floodgate located at the estuary of Haihe River. Dagu Drainage River flows through a chemical industry zone and three sampling sites were set along the river according to the location of the chemical factories in the chemical industrial area. In addition, as reference points, two samples from Yongdingxin River and Kaifaqu River flowing into Bohai Sea in Tianjin City were also collected in the estuaries in July 2003. Surface sediments (about $5 \mathrm{~cm}$ in depth) were collected with a grab sampler (Ekman grab, Wildlife Supply Company, Buffalo, US) and placed in pre-cleaned glass bottles. The samples were stored at $-20{ }^{\circ} \mathrm{C}$ until analysis.

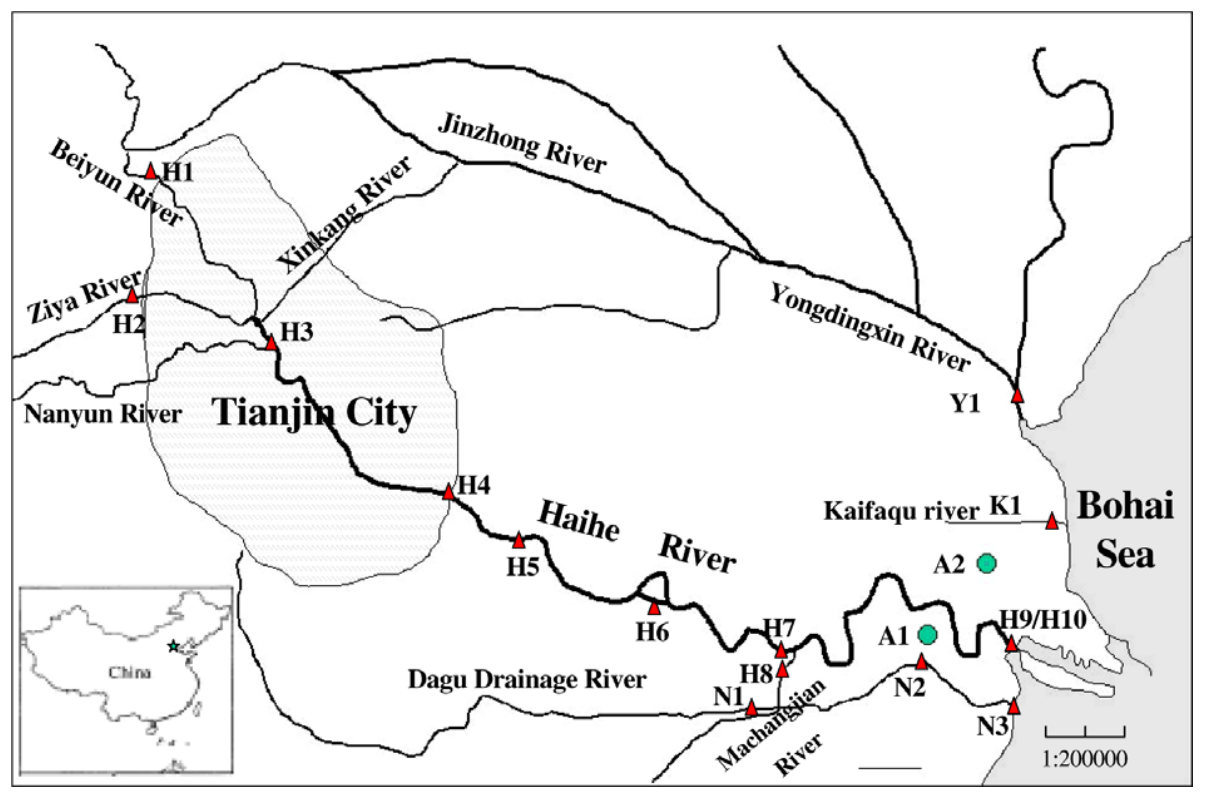

Fig. 1. Map of the Haihe River basin, Dagu Drainage River in Tianjin and sampling sites location (A1 and A2 are not sampling sites, A1: Chemical industry area; A2: Tianjin Economic and Technological Development Area) H1-H10, N1-N3, K1 and Y1 were collected along Haihe River, Dagu Drainage River, Kaifaqu River and Yongdingxin River, respectively. 


\subsection{Chemical reagents and standard solutions}

All solvents were of pesticide residue grade and were purchased from Fisher (Fair Lawn, USA). Silica gel $(0.063-0.100 \mathrm{~mm})$ was obtained from Merck (Darmstadt, Germany). Acidic alumina (150 mesh), Florisil (60-100 mesh) and Bio-Beams SX-3 were purchased from Aldrich (Milwaukee, USA), Riedel-de Haën (Seelze, German) and Bio-Rad (Richmond, USA), respectively. Standard solutions of PCDD/Fs and PCBs according to EPA methods 1613B (US EPA, 1997) and 1668A (US EPA, 1999) were obtained from Cambridge Isotope Laboratories (Andover, USA) and Wellington Laboratories (Guelph, Canada).

\subsection{Sample analysis procedure}

Detailed descriptions of the sample extraction and fractionation procedures have been reported elsewhere (Zhang and Jiang, 2005). Briefly, sediment samples were freeze-dried and $1-2 \mathrm{~g}$ dry samples were spiked with ${ }^{13} \mathrm{C}$-labeled surrogate standards prior to the 24-h Soxhlet extraction with toluene. All extracts were concentrated to about $2 \mathrm{ml}$ for the following cleanup except the extract of sediment of site $\mathrm{N} 3$, of which only $10 \%$ due to its higher pollution was used for following analysis. The extract was then sequentially subjected to multi-layer silica gel and acid alumina chromatography columns for cleanup. Florisil was also used for separating the analytes into two groups. For sediment samples rich in high molecular weight interferences, which cause degradation of GC column performance, gel permeation chromatography (GPC) is very necessary to cleanup the PCB fraction by removing this kind of interferences (US EPA, 1999; Ahmed, 2003; Saito et al., 2004). The fractions of PCBs extracted from sediments collected from the site H9, H10 and Dagu Drainage River (N1-N3) were further purified by GPC. Recovery standards, 1613-IS (for $\mathrm{PCDD} / \mathrm{Fs}$ ) and 68A-IS (for PCBs) were added prior to the GC injection.

The quantification was performed on an Agilent 6890 gas chromatography coupled with an Autosepc Ultima mass spectrometer operating in EI mode at $35 \mathrm{eV}$ and trap current of $600 \mathrm{~mA}$. Exactly $1 \mu \mathrm{l}$ of sample extract was injected with a CTC PAL autosampler in splitless mode into a DB-5MS fused silica capillary column $(60 \mathrm{~m} \times$ $250 \mu \mathrm{m}$ i.d. $\times 0.25 \mu \mathrm{m}$ film thickness, Agilent, USA). Helium was used as carrier gas with a constant flow of $1.2 \mathrm{ml} \mathrm{min}{ }^{-1}$. Details of MS analysis and quality control have been described elsewhere (Liu et al., 2006a).

Seventeen 2,3,7,8-substituted chlorinated congeners of PCDD/Fs, 12 WHO-specified PCBs, six indicator PCBs (CB28, 52, 101, 138, 153 and 180) and CB209 were quantitatively determined. Total PCDD/Fs and PCBs were calculated using total area of all the peaks detected in selected isobaric ions. The quality control (QC) of the method following QC of US-EPA methods 1613B and 1668A met the criteria of acceptance specified in the US-EPA methods, which has been reported in detail elsewhere (Zhang and Jiang, 2005).

In addition, total organic matter (TOM) was determined by method of weight loss-on-ignition. A representative portion of the dry sediment was transferred into a pre-weighed crucible and sample weight was determined using an analytical balance. Samples were burned at $550{ }^{\circ} \mathrm{C}$ for $6 \mathrm{~h}$ in muffle furnace (A) to remove organic matter. After cooling in a desiccator, samples were reweighed (B). TOM was determined as follows:

$\operatorname{TOM}(\%)=100-100 \times(A-B) \div A$

\section{Results and discussion}

The levels of $\mathrm{PCDD} / \mathrm{Fs}$ and $\mathrm{PCBs}$ in sediments are shown in Table 1. The concentrations of total PCDD/Fs and total PCBs in the surface sediments of the sampling sites ranged from 151 to $556961 \mathrm{pg} \mathrm{g}^{-1} \mathrm{dw}$ and 775 to $153727 \mathrm{pg} \mathrm{g}^{-1} \mathrm{dw}$, respectively. Though the pollution levels of PCBs were higher than those of PCDD/Fs in this study, the total TEQs for PCBs were far lower than PCDD/Fs' because indicator PCBs with zero TEF dominated $88-97$ percent contributions to total PCB congeners. Table 2 shows the total I-TEQ and WHO-TEQ for both PCDD/Fs and PCBs. TEQ were calculated based on the TEFs not only suggested by Ahlborg et al. (1994) but also revised WHO-TEFs for humans/mammals (Van den Berg et al., 1998) so as to compare pollution levels with other reported data. In addition, total WHO-TEQ for both PCDD/Fs and PCBs calculated based on the updated WHO-TEF were also list in Table 2 (Van den Berg et al., 2006).

\subsection{Pollution levels of PCDD/Fs and PCBs in Haihe River}

The concentration of total PCDD/Fs and TEQ in the surface sediments of the Haihe River and its tributary rivers ranged from 151 to $11546 \mathrm{pg} \mathrm{g}^{-1} \mathrm{dw}$ and $1.3-26 \mathrm{pg}$ I-TEQ $\mathrm{g}^{-1} \mathrm{dw}$, respectively. Comparing with the previous reports about the $\mathrm{PCDD} / \mathrm{Fs}$ in other river and coast sediments listed in Table 3, the levels of PCDD/Fs in Haihe River were not significant higher. Relatively higher concentrations were detected at the estuary (H10) and the Machangjian River (H8), one of tributary rivers of Haihe River. The total I-TEQ of PCDD/Fs and PCBs in $\mathrm{H} 8$ and $\mathrm{H} 10$ were 20 and $27 \mathrm{pg} \mathrm{TEQ} \mathrm{g}^{-1} \mathrm{dw}$, respectively, which have exceed the safe sediment value of $20 \mathrm{pg}^{2}$ TEQ g ${ }^{-1} \mathrm{dw}$ suggested by Evers et al. (1996). Because both of estuary and Machangjian River flow through the chemical industry zone, the heavier pollution might come from the chemical industry. Therefore, three sediments (N1-N3) were collected along the Dagu Drainage River, which flows into Bohai Sea through the chemical industrial area. The determined concentrations of PCDD/ Fs and PCBs (with TEQ) among three sediments (N1-N3) collected along the Dagu Drainage River, which 
Table 1

Concentrations of PCDD/Fs and PCBs in sediments from Haihe River, Dagu Drainage River, Kaifaqu River and Yongdingxin River (pg g ${ }^{-1} \mathrm{dw}_{\text {) }}$

\begin{tabular}{|c|c|c|c|c|c|c|c|c|c|c|c|c|c|c|c|}
\hline Compounds & H1 & $\mathrm{H} 2$ & $\mathrm{H} 3$ & $\mathrm{H} 4$ & H5 & H6 & $\mathrm{H} 7$ & $\mathrm{H} 8$ & H9 & $\mathrm{H} 10$ & K1 & Y1 & N1 & $\mathrm{N} 2$ & N3 \\
\hline 2378-TCDF & 1.5 & 0.8 & 2.8 & 3.0 & 1.8 & 1.4 & 1.2 & 1.4 & 1.1 & 1.7 & 0.4 & 2.4 & 7.6 & 0.9 & 74 \\
\hline 12378-PeCDF & 0.8 & 3.9 & 1.1 & 4.5 & 1.1 & 1.3 & 0.9 & 2.6 & 1.1 & 3.3 & 0.3 & 1.1 & 8.2 & 21 & 38 \\
\hline 23478-PeCDF & 1.0 & 3.1 & 1.5 & 3.6 & 0.8 & 1.6 & 0.3 & 3.2 & 1.8 & 2.9 & 0.2 & 0.5 & 8.1 & 61 & 94 \\
\hline 123478-HxCDF & 2.0 & 3.7 & 3.5 & 3.7 & 1.5 & 4.7 & 1.2 & 22 & 8.2 & 16 & 2.1 & 1.2 & 30 & 480 & 758 \\
\hline 123678-HxCDF & 1.9 & 3.0 & 1.8 & 3.0 & 1.0 & 2.0 & 0.8 & 4.2 & 1.0 & 2.8 & 0.6 & 0.8 & 7.2 & 69 & 76 \\
\hline 234678-HxCDF & 1.0 & 2.6 & 2.4 & 2.7 & 0.9 & 1.5 & 1.4 & 2.6 & 2.4 & 3.6 & 0.5 & 0.5 & 7.4 & 32 & 132 \\
\hline 123789-HxCDF & 0.7 & 1.2 & 0.7 & 1.2 & 0.2 & 0.5 & 0.2 & 0.6 & 0.1 & 0.9 & 0.1 & 0.5 & 1.0 & 1.0 & 13 \\
\hline 1234678-HpCDF & 7.2 & 8.3 & 15 & 9.0 & 5.3 & 13 & 4.3 & 41 & 17 & 75 & 4.7 & 3.4 & 47 & 464 & 2721 \\
\hline 1234789-HpCDF & 0.9 & 2.6 & 1.3 & 3.0 & 0.7 & 2.1 & 0.3 & 11 & 3.9 & 16 & 0.8 & 0.6 & 11 & 129 & 678 \\
\hline OCDF & 17 & 26 & 32 & 33 & 34 & 35 & 14 & 122 & 84 & 583 & 11 & 9.9 & 123 & 1223 & 32243 \\
\hline 2378-TCDD & 1.3 & 0.5 & 1.5 & 0.9 & 0.3 & 0.7 & 0.2 & 0.6 & 1.4 & 1.4 & 0.3 & 1.1 & 1.0 & 6.3 & 63 \\
\hline 12378-PeCDD & 0.9 & 2.3 & 1.0 & 3.0 & 0.4 & 0.6 & 0.2 & 1.8 & 1.3 & 3.4 & 0.3 & 0.6 & 4.5 & 32 & 172 \\
\hline 123478-HxCDD & 0.5 & 1.8 & 0.7 & 1.9 & 0.2 & 1.2 & 0.1 & 5.4 & 11 & 9.9 & 0.6 & 0.5 & 8.8 & 108 & 1304 \\
\hline 123678-HxCDD & 0.7 & 2.4 & 1.2 & 3.7 & 0.7 & 4.0 & 0.6 & 30 & 11 & 19 & 1.2 & 0.5 & 14 & 437 & 820 \\
\hline 123789-HxCDD & 1.4 & 2.7 & 0.8 & 3.0 & 0.3 & 1.5 & 0.1 & 16 & 5.1 & 5.2 & 0.5 & 0.5 & 9.7 & 237 & 381 \\
\hline 1234678-HpCDD & 12 & 10 & 12 & 30 & 4.9 & 68 & 8.4 & 513 & 162 & 427 & 30 & 7.9 & 152 & 6990 & 16786 \\
\hline OCDD & 104 & 79 & 180 & 227 & 32 & 515 & 66 & 2573 & 1811 & 9602 & 264 & 145 & 929 & 26294 & 476781 \\
\hline PCB-77 & 11 & 21 & 55 & 57 & 5.5 & 44 & 2.1 & 22 & 16 & 13 & 5.8 & 3.0 & 303 & 212 & 790 \\
\hline PCB-81 & 0.7 & 0.5 & 2.5 & 1.1 & 0.2 & 0.6 & 0.1 & 0.8 & 0.3 & 0.2 & 0.2 & 0.4 & 17 & 1.0 & 23 \\
\hline PCB-105 & 13 & 12 & 78 & 35 & 7.9 & 33 & 3.4 & 39 & 13 & 22 & 11 & 3.4 & 338 & 313 & 862 \\
\hline PCB-114 & 1.5 & 1.2 & 1.4 & 1.4 & 0.8 & 1.7 & 0.1 & 2.3 & 0.2 & 1.4 & 0.2 & 0.6 & 37 & 21 & 0.4 \\
\hline PCB-123 & 1.6 & 0.9 & 1.5 & 2.4 & 0.1 & 2.6 & 0.4 & 2.9 & 0.2 & 0.3 & 0.2 & 1.1 & 0.8 & 27 & 0.5 \\
\hline PCB-126 & 1.8 & 1.1 & 3.0 & 1.9 & 0.6 & 1.4 & 0.8 & 4.3 & 3.7 & 5.1 & 0.7 & 0.9 & 8.5 & 27 & 201 \\
\hline PCB-156 & 2.6 & 3.5 & 20 & 8.7 & 2.7 & 9.0 & 1.6 & 17 & 6.2 & 10 & 2.5 & 1.4 & 65 & 154 & 445 \\
\hline PCB-157 & 1.0 & 0.8 & 4.0 & 2.2 & 0.6 & 4.9 & 0.5 & 9.4 & 2.3 & 3.8 & 1.0 & 0.5 & 15 & 86 & 256 \\
\hline PCB-167 & 0.9 & 1.3 & 5.5 & 3.5 & 1.1 & 4.9 & 0.7 & 12 & 4.6 & 9.0 & 1.2 & 0.9 & 19 & 105 & 368 \\
\hline PCB-169 & 1.1 & 0.3 & 1.4 & 0.5 & 0.2 & 0.5 & 0.1 & 0.6 & 0.6 & 0.5 & 0.2 & 0.6 & 5.4 & 5.0 & 18 \\
\hline PCB-189 & 0.5 & 0.7 & 2.3 & 1.5 & 0.5 & 2.3 & 0.4 & 7.0 & 2.3 & 3.6 & 0.8 & 0.3 & 7.1 & 61 & 190 \\
\hline PCB-28 & 244 & 202 & 1753 & 480 & 70 & 647 & 45 & 363 & 125 & 111 & 96 & 82 & 18377 & 5435 & 1049 \\
\hline PCB-52 & 22 & 31 & 137 & 72 & 35 & 59 & 11 & 59 & 38 & 26 & 19 & 15 & 1465 & 467 & 414 \\
\hline PCB-101 & 23 & 27 & 113 & 69 & 25 & 74 & 13 & 111 & 103 & 105 & 28 & 10 & 1161 & 1835 & 4466 \\
\hline PCB-138 & 12 & 22 & 84 & 72 & 25 & 50 & 11 & 87 & 43 & 46 & 20 & 4.5 & 524 & 858 & 1828 \\
\hline PCB-153 & 20 & 29 & 118 & 90 & 30 & 95 & 13 & 84 & 95 & 98 & 30 & 6.7 & 606 & 944 & 3104 \\
\hline PCB-180 & 13 & 11 & 64 & 37 & 13 & 49 & 6.5 & 104 & 44 & 38 & 11 & 7.4 & 15 & 158 & 2024 \\
\hline PCB-209 & 15 & 127 & 55 & 59 & 25 & 58 & 7.9 & 169 & 1437 & 307 & 59 & 27 & 147 & 1005 & 55481 \\
\hline Total PCDD/Fs & 211 & 276 & 352 & 466 & 153 & 753 & 151 & 3808 & 2418 & 11546 & 372 & 210 & 1962 & 44946 & 556961 \\
\hline Total PCBs & 1583 & 1703 & 7473 & 3274 & 1142 & 3473 & 775 & 4424 & 3931 & 2990 & 1169 & 922 & 70325 & 44266 & 153727 \\
\hline
\end{tabular}

H1-H10 from Haihe River, N1-N3 from Dagu Drainage River, K1 from Kaifaqu River and Y1 from Yongdingxin River.

Table 2

TEQs for PCDD/Fs and PCBs using WHO-TEFs and I-TEFs (pg TEQ $\mathrm{g}^{-1} \mathrm{dw}$ )

\begin{tabular}{|c|c|c|c|c|c|c|c|c|c|c|c|c|c|c|c|}
\hline Sampling sites & H1 & $\mathrm{H} 2$ & $\mathrm{H} 3$ & $\mathrm{H} 4$ & H5 & H6 & H7 & $\mathrm{H} 8$ & H9 & $\mathrm{H} 10$ & K1 & Y1 & N1 & $\mathrm{N} 2$ & N3 \\
\hline WHO-TEQ (PCDD/Fs) ${ }^{\mathrm{a}}$ & 4.9 & 7.4 & 6.4 & 8.8 & 1.9 & 5.5 & 1.4 & 18 & 9.7 & 19 & 1.7 & 8.2 & 21 & 28 & 89 \\
\hline WHO-TEQ (PCBs) ${ }^{\mathrm{a}}$ & 0.20 & 0.13 & 0.36 & 0.21 & 0.07 & 0.22 & 0.09 & 0.46 & 0.39 & 0.53 & 0.08 & 0.09 & 1.2 & 3.0 & 21 \\
\hline Total WHO-TEQ ${ }^{\mathrm{a}}$ & 5.1 & 7.6 & 6.8 & 9.0 & 1.9 & 5.7 & 1.5 & 19 & 10 & 19 & 1.7 & 8.3 & 22 & 288 & 914 \\
\hline I-TEQ $(\mathrm{PCDD} / \mathrm{Fs})^{\mathrm{b}}$ & 3.6 & 5.5 & 4.7 & 7.3 & 1.8 & 4.9 & 1.3 & 20 & 11 & 26 & 1.8 & 2.7 & 19 & 294 & 1264 \\
\hline TEQ (PCBs) ${ }^{\mathrm{b}}$ & 0.20 & 0.13 & 0.38 & 0.24 & 0.07 & 0.19 & 0.08 & 0.47 & 0.40 & 0.54 & 0.08 & 0.10 & 1.2 & 3.0 & 21 \\
\hline Total TEQ ${ }^{\mathrm{b}}$ & 3.8 & 5.7 & 5.1 & 7. 6 & 1.9 & 5.1 & 1.4 & 20 & 11 & 27 & 1.9 & 2.8 & 21 & 297 & 1286 \\
\hline WHO-TEQ (PCDD/Fs) ${ }^{\mathrm{c}}$ & 3.7 & 5.9 & 4.7 & 7.8 & 1.8 & 4.5 & 1.2 & 18 & 9.6 & 20 & 1.7 & 2.7 & 19 & 278 & 975 \\
\hline WHO-TEQ $(\mathrm{PCBs})^{\mathrm{c}}$ & 0.2 & 0.1 & 0.4 & 0.2 & 0.1 & 0.2 & 0.1 & 0.5 & 0.4 & 0.5 & 0.1 & 0.1 & 1.1 & 2.8 & 21 \\
\hline Total WHO-TEQ ${ }^{\mathrm{c}}$ & 3.9 & 6.0 & 5.1 & 8.0 & 1.8 & 4.6 & 1.3 & 19 & 10.0 & 21 & 1.8 & 2.8 & 20 & 281 & 996 \\
\hline
\end{tabular}

${ }^{\text {a }}$ Van den Berg et al. (1998).

b Ahlborg et al. (1994).

${ }^{\mathrm{c}}$ Van den Berg et al. (2006).

flows into Bohai Sea through the chemical industrial area, were up to $557 \mathrm{ng} \mathrm{g}^{-1} \mathrm{dw}$ (1264 $\mathrm{pg} \mathrm{I}^{-T E Q ~ g}{ }^{-1} \mathrm{dw}$ ) and $154 \mathrm{ng} \mathrm{g}^{-1} \mathrm{dw}$ (21 pg TEQ $\left.\mathrm{g}^{-1} \mathrm{dw}\right)$, respectively. These results indicate that the Dagu Drainage River is the most heavily polluted with levels of PCDD/Fs and PCBs significantly above the safe sediment level of $20 \mathrm{pg}^{\text {TEQ }} \mathrm{g}^{-1} \mathrm{dw}$. 
Table 3

Levels of PCDD/Fs and PCBs in surface sediments from rivers and coasts

\begin{tabular}{|c|c|c|c|c|c|c|c|}
\hline \multirow[t]{2}{*}{ Location } & \multicolumn{3}{|c|}{ Concentration $\left(\mathrm{pg} \mathrm{g}^{-1} \mathrm{dw}\right)$} & \multicolumn{3}{|c|}{ TEQ $\left(\mathrm{pg} \mathrm{g}^{-1} \mathrm{dw}\right)$} & \multirow[t]{2}{*}{ References } \\
\hline & PCDDs & PCDFs & PCBs & PCDDs & PCDFs & PCBs & \\
\hline Haihe River, China & \multicolumn{2}{|c|}{$151-556961$} & $775-153727$ & $\begin{array}{l}1.4-19^{\mathrm{a}} \\
1.3-26^{\mathrm{b}}\end{array}$ & & $\begin{array}{l}0.07-0.53^{\mathrm{a}} \\
0.07-0.54^{\mathrm{b}}\end{array}$ & \multirow[t]{2}{*}{ This study } \\
\hline Dagu Drainage River, China & \multicolumn{2}{|c|}{$1962-556961$} & $44266-153727$ & $\begin{array}{l}21-893^{\mathrm{a}} \\
19-1264^{\mathrm{b}}\end{array}$ & & $\begin{array}{l}1.2-21^{\mathrm{a}} \\
1.2-21^{\mathrm{b}}\end{array}$ & \\
\hline Taihu Lake, China & \multicolumn{2}{|c|}{$120.1-1315.1$} & $889.7-29747.8$ & \multicolumn{3}{|c|}{$0.83-17.72^{\mathrm{a}}$} & Zhang and Jiang (2005) \\
\hline Yaer Lake, China & \multicolumn{2}{|c|}{$3918-13845$} & - & \multicolumn{2}{|c|}{$10-420^{\mathrm{b}}$} & - & Wu et al. (2001) \\
\hline Coast, Hong Kong & \multicolumn{2}{|c|}{$310-11000$} & - & \multicolumn{2}{|c|}{$3.0-33^{\mathrm{b}}$} & - & Müller et al. (2002) \\
\hline Tokyo Bay, Japan & \multicolumn{2}{|c|}{-} & - & \multicolumn{2}{|c|}{$3.1-49^{\mathrm{a}}$} & $0.18-3.0^{\mathrm{a}}$ & Hosomi et al. (2003) \\
\hline River Po, Italy & \multicolumn{2}{|c|}{$121-814$} & - & \multicolumn{2}{|c|}{$1.3-13^{\mathrm{a}}$} & - & Fattore et al. (2002) \\
\hline Hyeongsan River, Korea & $2.6-1200$ & $2.2-640$ & $10-10000$ & $0.16-937^{\mathrm{a}}$ & $0.22-197^{\mathrm{a}}$ & $0.05-3.37^{\mathrm{a}}$ & Koha et al. (2004) \\
\hline Venice Lagoon, Italy & $16-13642$ & $49-126561$ & $2-2049$ & \multicolumn{2}{|c|}{$0.5-2857^{\mathrm{b}}$} & $0.05-404^{\mathrm{b}}$ & $\begin{array}{l}\text { Bellucci et al. (2000) } \\
\text { Frignani et al. (2001) }\end{array}$ \\
\hline Southern Mississippi, USA & $1.7-7206$ & $0.06-126$ & - & \multicolumn{2}{|c|}{$1.3-619$} & - & Rappe et al. (1997) \\
\hline Coast, Spain & \multicolumn{2}{|c|}{$121-12037$} & $22-30007$ & & $48^{\mathrm{a}}$ & $0.2-63^{\mathrm{a}}$ & Eljarrat et al. (2005) \\
\hline Harbour of Hamburg, Germany & \multirow{2}{*}{\multicolumn{2}{|c|}{-}} & - & \multirow{2}{*}{\multicolumn{3}{|c|}{$\begin{array}{c}25.6-174.2^{\mathrm{b}} \\
82^{\mathrm{b}}\end{array}$}} & Götz et al. (1998) \\
\hline River Elbe, Germany & & & - & & & & \\
\hline
\end{tabular}

a Van den Berg et al. (1998).

b Ahlborg et al. (1994).

PCDD/Fs in sediments collected from Dagu Drainage River were significantly higher than other areas except for the Venice lagoon (Table 3). The pollution of PCDD/ Fs and PCBs were sharply increased along the flow direction of Dagu Drainage River, indicating that the pollutions might come from the chemical industry. In addition, it was reported that the concentrations of mercury and organochlorine pesticides in sediments from Dagu Drainage River were also very high (Shi et al., 2005; Yang et al., 2005). Therefore, more attention should be paid and further investigation should be done for this area. The pollution levels of PCBs, $0.07-0.54 \mathrm{pg} \mathrm{I}^{-T E Q ~ g} \mathrm{~g}^{-1} \mathrm{dw}$, were very low in Haihe River. Significant PCBs pollution was found in N3 with 21 pg I-TEQ g ${ }^{-1} \mathrm{dw}$, beyond the safety level of sediment.

$\mathrm{PCDD} / \mathrm{Fs}$ and $\mathrm{PCBs}$ levels in site $\mathrm{H} 10$ were higher than that of site H9. These two sites, H9 and H10, were just separated with a floodgate at the estuary of Haihe River. The potential pollution might come from the sewage outlet of the Dagu Drainage River at the south of H10. The estuary of Haihe River might be polluted easily by the effluents of Dagu Drainage River (Jin et al., 2004). Also, as shown in Fig. 2, similar congener profile was found between sites of $\mathrm{H} 10$ and N3. However, H9 was less contaminated due to the protection of the floodgate. Moreover, this result is accord with the report (Liu et al., 2006b), in which higher levels of PCP were found in sea than in river due to the salinity change between them.

In addition, samples collected from Kaifaqu River and Yongdingxin River, as reference points, were also analyzed to assess the pollution level of rivers flowing into Bohai Sea in Tianjin City sediment. Low levels of PCDD/Fs and PCBs were detected in these two rivers with TEQ of 1.8 and $0.08,2.7$ and $0.10 \mathrm{pg}$ I-TEQ $\mathrm{g}^{-1} \mathrm{dw}$, respectively.

\subsection{Profile and possible sources of PCDD/Fs}

Similar congener profile, in which OCDD was the most abundant congener followed by OCDF and 1,2,3,4,6,7,8HpCDD, was found throughout Haihe River. The profile of PCDD/Fs in Haihe River, Dagu Drainage River and two other rivers in Tianjin is in accord with the profiles reported in other sediments of rivers (Eljarrat et al., 2005; $\mathrm{Hu}$ et al., 2005; Zhang and Jiang, 2005). Percentage contributions of OCDD, HpCDD and OCDF to the totalPCDD/Fs were shown in Fig. 2. The profiles of PCDD/ Fs in the tested sediments were consisted with the profile of main dominant congeners of impurities (OCDD $(76 \%)$ as well as OCDF (10\%) and 1,2,3,4,6,7,8-HpCDD (10\%)) in PCP and PCP-Na (Bao et al., 1995). Higher percentages of OCDD were found in sites of H9, H10 and N3. These three sampling sites were all at the downstream of the rivers flowing though the chemical industrial area where the PCP and PCP-Na have been manufactured for nearly half a century. Moreover, relatively higher or significant high concentrations were detected at the sampling sites located around the chemical industrial areas. In view of that, the source of the heavier PCDD/Fs pollutions in this area might come from the effluent of PCP and PCP-Na production.

\subsection{Correlation between PCBS/PCDD/Fs and TOM}

TOM in the 13 sediment samples except the three sediment samples collected from Dagu Drainage River, N1$\mathrm{N} 3$ neared to pollution resource, was determined. The relationship between the concentration of PCBs and the data of TOM was investigated and presented in Fig. 3. The linear regression correlation between PCBs and TOM was 0.34 . Thus, the concentrations of PCBs were 


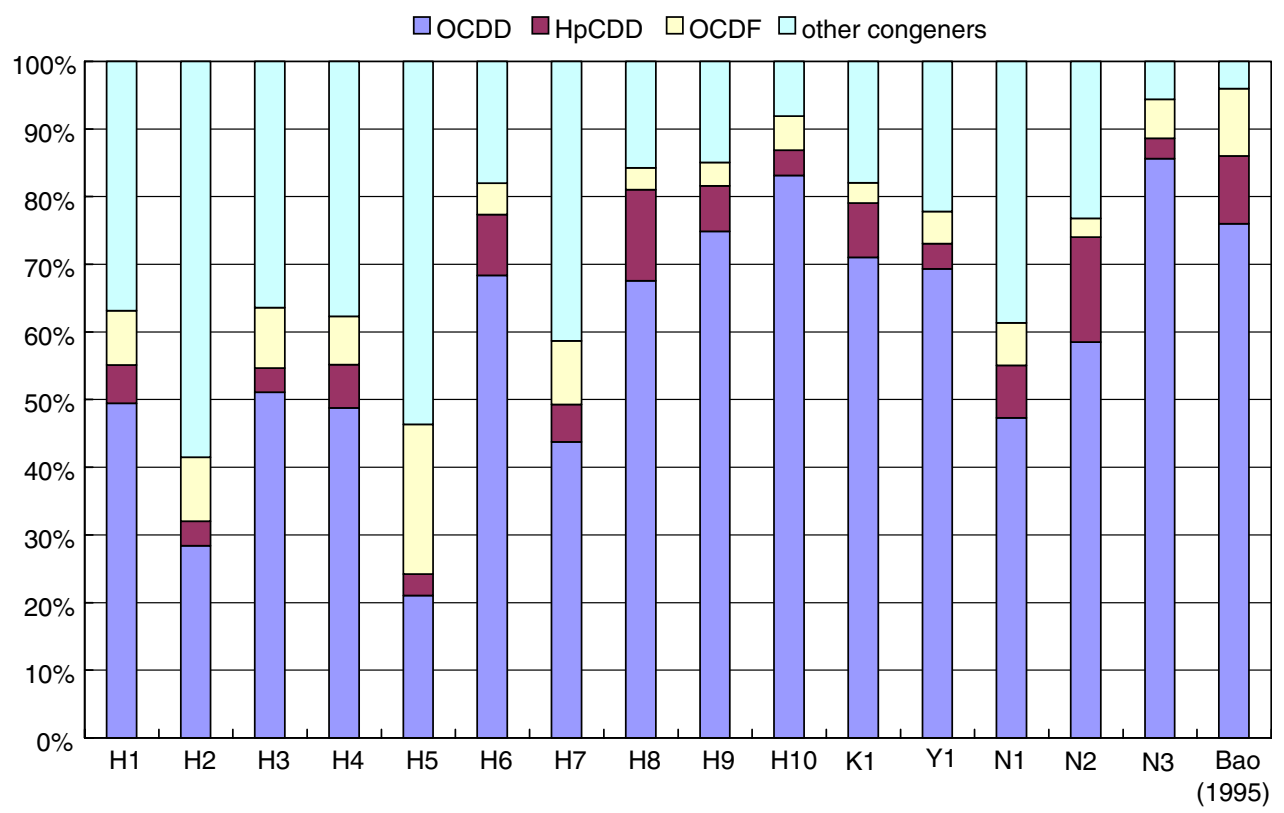

Fig. 2. Percentage contributions of OCDD, HpCDD and OCDF to the total-PCDD/Fs for all sediments samples and impurities in PCP and PCP-Na reported by Bao et al. (1995).

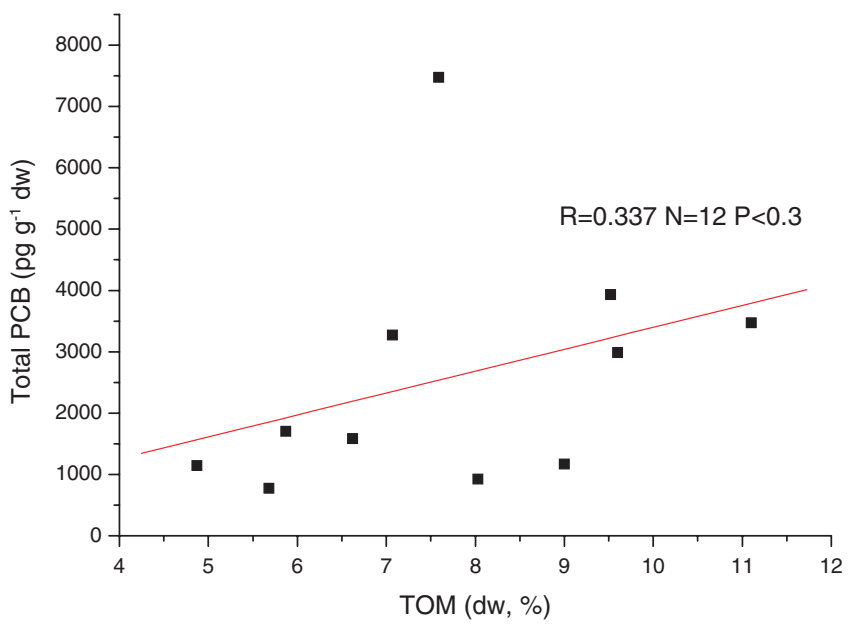

Fig. 3. Relationship between PCBs and TOM. (Data matrix without N1N3 neared to pollution resource was used.)

independent on the TOM of sediments. It is in accord with the result reported by Buckley et al. (2004) and Mai et al. (2005). But it differs from that of Jeong et al. (2001), in which significant correlation was found between PCBs and total organic carbon.

The relationship between PCDD/Fs and TOM was similar to that between PCBs and TOM with correlation coefficient of 0.21 .

\section{Conclusions}

The pollution resource of PCDD/Fs and PCBs in sediments from Bohai Sea and the pollution status of PCDD/Fs and PCBs in rivers in Tianjin City were investigated. The levels of PCDD/Fs and PCBs in Haihe River were lower than the value of safe sediment for samples from all sampling sites except for sites of $\mathrm{H} 8$ and $\mathrm{H} 10$. Comparing with the levels reported in literatures, significant contamination of PCDD/Fs and PCBs was found in Dagu Drainage River. The pollution source of PCBs could not be identified. But congener profiles of PCDD/Fs indicate that the production of PCP or PCP-Na may be one source of $\mathrm{PCDD} / \mathrm{Fs}$ in this area.

\section{Acknowledgements}

This work is jointly supported by National Basic Research Program of China (2003CB415001), the Distinguished Young Scholar Award of the National Science Foundation of China (20329701) and National Natural Science Foundation of China (20607025).

\section{References}

Ahlborg, U., Becking, G., Birnbaum, L., Brouwer, A., Derks, H., Feeley, M., Golor, G., Hanberg, A., Larsen, J., Liem, A., Safe, S., Schlatter, C., Waern, F., Younes, M., Yrjänheikki, E., 1994. Toxic equivalency factors for dioxin-like PCBs: report on a WHO-ECEH and IPCS consultation, December 1993. Chemosphere 28, 1049-1067.

Ahmed, F., 2003. Analysis of polychlorinated biphenyls in food products. Trends Anal. Chem. 22, 170-185.

Bao, Z., Wang, K., Kang, J., Zhao, L., 1995. Analysis of polychlorinated dibenzo-p-dioxins and polychlorinated dibenzofurans in pentachlorophenol and sodium pentachlorophenate. Environ. Chem. 14, 317-321 (in Chinese).

Bellucci, L., Frignani, M., Raccanelli, S., Carraro, C., 2000. Polychlorinated dibenzo-p-dioxins and dibenzofurans in surficial sediments of the Venice Lagoon (Italy). Marine Pollut. Bull. 40, 65-76.

Buckley, D., Rockne, K., Li, A., Mills, W., 2004. Soot deposition in the great lakes: implications for semi-volatile hydrophobic organic pollutant deposition. Environ. Sci. Technol. 38, 1732-1739. 
Cheng, W., Coenraads, P., Hao, Z., Liu, G., 1993. A health survey of workers in the pentachlorophenol section of a chemical manufacturing plant. Am. J. Ind. Med. 24, 81-92.

Ding, H., Li, X., Sun, Y., Shen, X., Shao, W., 2005. The discussion about organic material pollutions in main stream of the Haihe river. Irrigation Works of Haihe 2, 18-20 (in Chinese).

Eljarrat, E., De La Cal, A., Larrazabal, D., Fabrellas, B., FernandezAlba, A., Borrull, F., Marce, R., Barcelo, D., 2005. Occurrence of polybrominated diphenylethers, polychlorinated dibenzo- $p$-dioxins, dibenzofurans and biphenyls in coastal sediments from Spain. Environ. Pollut. 136, 493-501.

Evers, E., Laane, R., Groeneveld, G., Olie, K., 1996. Levels, temporal trends and risk of dioxins and related compounds in the Dutch aquatic environment. Organohalogen Compd. 28, 117-122.

Fattore, E., Vigan, L., Mariani, G., Guzzi, A., Benfenati, E., Fanelli, R., 2002. Polychlorinated dibenzo- $p$-dioxins and dibenzofurans in River Po sediments. Chemosphere 49, 749-754.

Frignani, M., Bellucci, L., Carraro, C., Raccanelli, S., 2001. Polychlorinated biphenyls in sediments of the Venice Lagoon. Chemosphere 43, $567-575$.

Gong, Z., Xu, F., Dawson, R., Cao, J., Liu, W., Li, B., Shen, W., Zhang, W., Qin, B., Sun, R., Tao, S., 2004. Residues of hexachlorocyclohexane isomers and their distribution characteristics in soils in the Tianjin area, China. Arch. Environ. Contam. Toxicol. 46, 432-437.

Götz, R., Steiner, B., Friesel, P., Roch, K., Walkow, F., Maaß, V., Reincke, H., Stachel, B., 1998. Dioxin (PCDD/F) in the river Elbe investigations of their origin by multivariate statistical methods. Chemosphere 37, 1987-2002.

Hagenmaier, H., Hermann, B., 1987. Isomerspecific analysis of pentachlorophenol and sodium pentachlorophenate for 2,3,7,8-substituted PCDD and PCDF at sub-ppb levels. Chemosphere 16, 1759-1764.

Hosomi, M., Matsuo, T., Dobashi, S., Katou, S., Abe, H., 2003. Survey of dioxins in Tokyo Bay bottom sediment. Marine Pollut. Bull. 47, 68-73.

Hu, J., Wang, Y., Shao, B., Jin, X., An, W., Jin, F., Yang, M., Wang, X., Sugisaki, M., 2005. Occurrence of trace organic contaminants in Bohai Bay and its adjacent Nanpaiwu River, North China. Marine Chem. 95, $1-13$.

Jeong, G., Kim, H., Joo, Y., Kim, Y., So, H., 2001. Distribution characteristics of PCBs in the sediments of the lower Nakdong River, Korea. Chemosphere 44, 1403-1411.

Jin, X., Jiang, G., Huang, G., Liu, J., Zhou, Q., 2004. Determination of 4tert-octylphenol, 4-nonylphenol and bisphenol $\mathrm{A}$ in surface waters from the Haihe River in Tianjin by gas chromatography-mass spectrometry with selected ion monitoring. Chemosphere 56, 11131119.

Koha, C., Khima, J., Kannanb, K., Villeneuvec, D., Senthilkumard, K., Giesyc, J., 2004. Polychlorinated dibenzo-p-dioxins (PCDDs), dibenzofurans (PCDFs), biphenyls (PCBs), and polycyclic aromatic hydrocarbons (PAHs) and 2,3,7,8-TCDD equivalents (TEQs) in sediment from the Hyeongsan River, Korea. Environ. Pollut. 132, 489-501.

Liu, H., Zhang, Q., Cai, Z., Li, A., Wang, Y., Jiang, G., 2006a. Separation of polybrominated diphenyl ethers, polychlorinated biphenyls, polychlorinated dibenzo- $p$-dioxins and dibenzo-furans in environmental samples using silica gel and florisil fractionation chromatography. Anal. Chim. Acta 557, 314-320.

Liu, J., Hu, J., Wan, Y., An, W., 2006b. Distribution of pentachlorophenol in sediments and water from Haihe basin and Bohai bay. Environ. Chem. 25 (5), 539-542 (in Chinese).

Mai, B., Zeng, E., Luo, X., Yang, Q., Zhang, G., Li, X., Sheng, G., Fu, J., 2005. Abundances, depositional fluxes, and homologue patterns of polychlorinated biphenyls in dated sediment cores from the pearl river delta, China. Environ. Sci. Technol. 39, 49-56.

Müller, J., Gaus, C., Prange, J., Päpke, O., Poon, K., Lam, M., Lam, P., 2002. Polychlorinated dibenzo-p-dioxins and polychlorinated dibenzofurans in sediments from Hong Kong. Marine Pollut. Bull. 45, 372-378.
Qin, B., Zhai, D., Yuan, Q., Zhang, Y., 1998. Study on the aquatic ecosystem of Haihe River. Chinese J. Urban Environ. Urban Ecol. 11, 48-51 (in Chinese).

Rappe, C., Kjeller, L., Kulp, S., de Wit, C., Hasselsten, I., Palm, O., 1991. Levels, profile and pattern of PCDDs and PCDFs in samples related to the production and use of chlorine. Chemosphere 23, 1629-1636.

Rappe, C., Anderssonl, R., Bonner, M., Cooper, K., Fiedleri, H., Howells, F., Kulpl, S., Laud, C., 1997. PCDDs and PCDFs in soil and river sediment samples from a rural area in the United States of America. Chemosphere 34, 1297-1314.

Saito, K., Sjödin, A., Sandau, C., Davis, M., Nakazawa, H., Matsuki, Y., Patterson Jr., D., 2004. Development of a accelerated solvent extraction and gel permeation chromatography analytical method for measuring persistent organohalogen compounds in adipose and organ tissue analysis. Chemosphere 57, 373-381.

Shi, J., Liang, L., Jiang, G., Jin, X., 2005. The speciation and bioavailability of mercury in sediments of Haihe River, China. Environ. Int. $31,357-365$.

Song, X., 2000. Review chloralkali production in China. Chinese J. Dagu Chem. Ind. 1, 2-3 (in Chinese).

Song, X., 2001. Development of chloralkali production of Dagu chemical plant. Chinese J. Dagu Chem. Ind. 2, 2-6 (in Chinese).

US EPA, 1997. Method 1613.

US EPA, 1999. Method 1668 Revision A.

Van den Berg, M., Birnbaum, L., Bosveld, A., Brunström, B., Cook, P., Feeley, M., Giesy, J., Hanberg, A., Hasegawa, R., Kennedy, S., Kubiak, T., Larsen, J., van Leeuwen, F., Liem, A., Nolt, C., Peterson, R., Poellinger, L., Safe, S., Schrenk, D., Tillit, D., Tysklind, M., Younes, M., Waern, F., Zacharewski, T., 1998. Toxic equivalency factors (TEFs) for PCBs, PCDDs, PCDFs for humans and wildlife. Environ. Health Perspect. 106, 775-792.

Van den Berg, M., Birnbaum, L., Denison, M., De Vito, M., Farland, W., Feeley, M., Fiedler, H., Hakansson, H., Hanberg, A., Haws, L., Rose, M., Safe, S., Schrenk, D., Tohyama, C., Tritscher, A., Tuomisto, J., Tysklind, M., Walker, N., Peterson, R., 2006. The 2005 WHO reevaluation of human and mammalian toxic equivalency factors for dioxin and dioxin-like compounds. Toxicol. Sci. 93, 223-241.

Wan, Y., Hu, J., Wang, M., An, L., An, W., Jin, X., Hattori, T., Itoh, M., 2005. Characterization of trophic transfer for polychlorinated dibenzop-dioxins, dibenzofurans, non-and mono-ortho polychlorinated biphenyls in the marine food web of Bohai Bay, North China. Environ. Sci. Technol. 39, 2417-2425.

Wu, W., Schramm, K., Xu, Y., Kettrup, A., 2001. Mobility and profiles of polychlorinated dibenzo-p-dioxins and dibenzofurans in sediment of Ya-Er Lake, China. Water Res. 35, 3025-3033.

Xu, Y., Zhang, Q., Wu, W., Li, W., 2000. Patterns and levels of PCDD/F in a Chinese graphite electrode sludge. Chinese Sci. Bull. 45, 14711475.

Yang, R., Lv, A., Shi, J., Jiang, G., 2005. The levels and distribution of organochlorine pesticides (OCPs) in sediments from the Haihe River, China. Chemosphere 61, 347-354.

Zhang, Q., Jiang, G., 2005. Polychlorinated dibenzo-p-dioxins/furans and polychlorinated biphenyls in sediments and aquatic organisms from the Taihu Lake, China. Chemosphere 61, 314-322.

Zhao, X., Zheng, M., Liang, L., Zhang, Q., Wang, Y., Jiang, G., 2005. Assessment of PCBs and PCDD/Fs along the Chinese Bohai Sea coastline by using mollusks as bioindicator. Arch. Environ. Contam. Toxicol. 49, 178-185.

Zhen, M., Qian, X., Cheng, G., Lu, D., 1999. The environmental function and quality standard of surface water in Tianjin. Chinese J. Urban Environ. Urban Ecol. 12, 10-12 (in Chinese).

Zheng, M., Bao, Z., Wang, K., Yang, H., Xu, X., 1997. Polychlorinated dibenzo-p-dioxins and dibenzofurans in lake sediments from Chinese schistosomiasis areas. Bull. Environ. Contam. Toxicol. 59, 653-656.

Zheng, M., Bao, Z., Zhang, B., Xu, X., 2001. Polychlorinated dibenzo-pdioxins and dibenzofurans in paper making from a pulp mill in China. Chemosphere 44, 1335-1337. 